OPEN ACCESS

Citation: Kean Roe F. Mazo, Jayson A. Mansibang, Lowell G. Aribal, Maverick N. Tamayo (2021) You 'Sau'Me! Anew species and a rediscovery in the genus Saurauia (Actinidiaceae) from Zamboanga Peninsula, Mindanao Island, Philippines. Webbia. Journal of Plant Taxonomyand Geography76(2):203-212. doi: 10.36253/jopt-10712

Received: March 29, 2021

Accepted: June 7, 2021

Published: September 7, 2021

Copyright: (C) 2021 Kean Roe F. Mazo, Jayson A. Mansibang, Lowell G. Aribal, Maverick N. Tamayo. This is an open access, peer-reviewed article published by Firenze University Press (http:// www.fupress.com/webbia) and distributed under the terms of the Creative Commons Attribution License, which permits unrestricted use, distribution, and reproduction in any medium, provided the original author and source are credited.

Data Availability Statement: All relevant data are within the paper and its Supporting Information files.

Competing Interests: The Author(s) declare(s) no conflict of interest.

Editor: Riccardo M. Baldini

ORCID

KRFM: https://orcid.org/0000-00025131-9084

JAM: https://orcid.org/0000-0003-1470-

2380

LGA: https://orcid.org/0000-0002-8530-

3267

MNT: https://orcid.org/0000-0003-0157-

5116

\section{You 'Sau' Me! A new species and a rediscovery in the genus Saurauia (Actinidiaceae) from Zamboanga Peninsula, Mindanao Island, Philippines}

\author{
Kean Roe F. Mazo ${ }^{1, *}$, Jayson A. Mansibang ${ }^{2}$, Lowell G. Aribal ${ }^{3}$, Maver- \\ ICK N. TAMAYO ${ }^{4}$ \\ ${ }^{1}$ Department of Forestry, College of Forestry and Environmental Studies, Western Mind- \\ anao State University, San Ramon, Talisayan, Zamboanga City, Philippines 7000 \\ ${ }^{2}$ Philippine Taxonomic Initiative, Inc., El Nido, Palawan, Philippines 5313 \\ ${ }^{3}$ Forest Biological Sciences Department, College of Forestry and Environmental Science, \\ Central Mindanao University, Bukidnon, Philippines 8714 \\ ${ }^{4}$ Department of Biology, College of Science, University of the Philippines Baguio, Baguio \\ City, Philippines 2600 \\ ${ }^{\star}$ Corresponding author. Email: kean.mazo@wmsu.edu.ph
}

\begin{abstract}
A new species and a rediscovery in the genus Saurauia (Actinidiaceae) from Zamboanga Peninsula, Mindanao island, Philippines are presented here. The new species, Saurauia abbreviata, closely resembles Saurauia lanaensis Merr. but can be differentiated by having longer petioles, uniformly setose adaxial leaf surface, longer and wider leaves, more lateral veins, 3 styles, and a 3(-4)-locular ovary. This discovery raises the current number of recognized Saurauia in the Philippines to 57 following an 87-year gap in the taxonomic study of this genus in the country. S. longipedicellata Merr. is also rediscovered after almost a century. A lectotype is here assigned for this name selected among the syntypes. Photographs, ecological notes, and an amended description are also provided to aid taxonomic identification.
\end{abstract}

\begin{abstract}
Abstrak. Usa ka bag-ong species ug nadiskobrehan pag-usab sa genus nga Saurauia (Actinidiaceae) gikan sa Zamboanga Peninsula, isla sa Mindanao, Philippines ang gipresentar dinhi. Ang bag-ong species, Saurauia abbreviata, nahisama pag-ayo sa Saurauia lanaensis Merr. apan ang bag-ong species adunay labi ka taas nga mga petioles, uniformly setose ang ilalom nga dahon, mas taas ug mas lapad nga dahon, labi pang mga lateral veins, 3 styles, ug 3(-4)-locular nga obaryo. Ang nadiskobrehan nagdugang sa kadaghanon sa mga giila nga Saurauia sa Pilipinas ngadto sa 57 human sa 87 ka tuig nga gintang sa taxonomic nga pagtuon sa kini nga genus sa nasud. Ang Saurauia longipedicellata Merr. nadiskobrehan usab pagkahuman sa hapit usa ka gatus ka tuig. Ang tipipikasyon gihimo dinhi aron mapalig-og ang ngalan. Mga litrato, mga notang ekolohikal, ug giusab nga hulagway alang sa maong species makita usab dinhi.
\end{abstract}

Keywords: Actinidia, Actinidiaceae, endemism, Philippines, taxonomy. 


\section{INTRODUCTION}

Saurauia Willd. is a large genus currently composed of ca. 300 species distributed in the tropical and sub-tropical areas of both the old and new worlds (Briggs 2015). Together with the genera Actinidia Lindl. and Clematoclethra (Franch.) Maxim., Saurauia is currently included in the family Actinidiaceae Engl. \& Gilg (POWO 2019). Advancement in the taxonomy of Saurauia has been hampered due to the extent of morphological variation within species being largely undetermined. This has made species delineation difficult, and recognizing undescribed taxa very challenging (Conn \& Damas 2013), especially in the Malesian Region where a great diversity of this taxon is largely unknown up to date.

The first species of Saurauia described for the Philippines, S. latibractea Choisy, was based on a collection by Hugh Cuming, who collected natural history collections there from 1836 to 1839 (van Welzen 2017). Elmer Drew Merrill continued the advancement in the study of this genus during the American occupation of the Philippines with 6 species published in the Govt. Lab. Publ. 35 (Merrill 1906). He likewise mentioned 48 species in his Enum. Philipp. Flow. Plants (EPFP) III (1923) and EPFP IV (1925). Moreover, S. gigantifolia Quisumb. and S. knemifolia Quisumb. were added to the list in 1944. Leonard Co updated the species checklist containing 56 taxon [excluding S. cordata Quisumb., the name however is accepted in the current checklist (Pelser et al. 2011 onwards)]. His unfinished manuscript laid the foundation of Co's Digital Flora of the Philippines (philippineplants.org) (Barcelona et al. 2013), an updated checklist of Philippine vascular plants (Pelser et al. 2011 onwards). This online database currently recognizes 56 species of

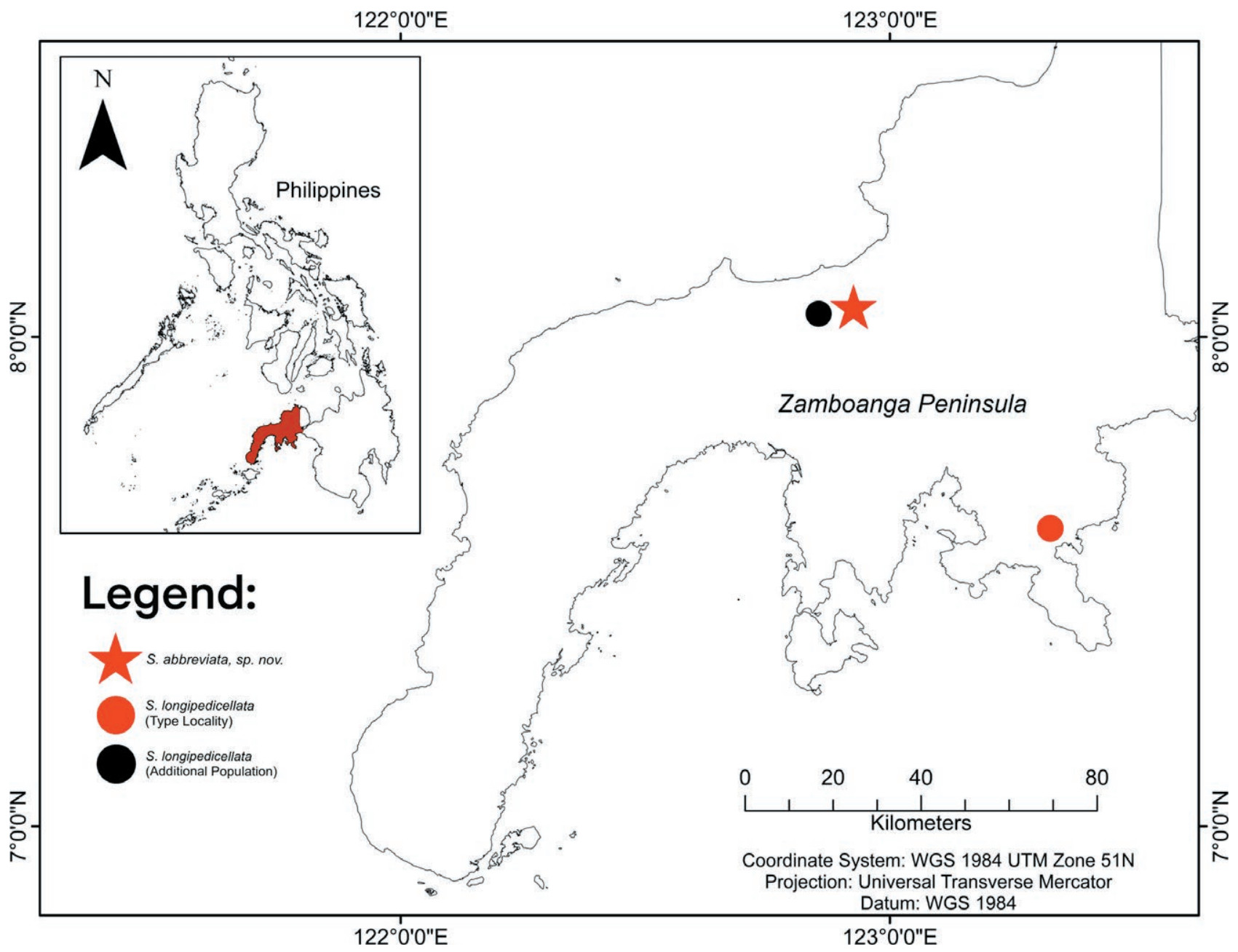

Figure 1. Map of Zamboanga peninsula showing the type locality of S. abbreviata denoted by (star); type locality of $S$. longipedicellata denoted by (red dot); additional population denoted by (black dot). Map created by Kean Roe Mazo. 
Saurauia. There are currently 20 species recorded on the island of Mindanao.

The Zamboanga peninsula (Fig. 1) in Mindanao island comprises 3 provinces: Zamboanga del Norte, Zamboanga del Sur, and Zamboanga Sibugay. This region is regarded as one of the cultural and ecological centers of the island. Historically, Zamboanga flora had been extensively studied through various expeditions in the 1900s. These expeditions generated specimens of a number of narrowly endemic species-many of which are yet to be rediscovered in the wild. Some noteworthy endemic plants are Aeschynanthus zamboangensis Kraenzl., Begonia zamboangensis Merr., Cymboglossum zamboangense (Ames) Ormerod \& Cootes, and Pandanus zamboangensis Martelli.

During fieldwork in the Municipality of Leon B. Postigo in Zamboanga del Norte, the first author documented an interesting Saurauia species bearing small, few-flowered axillary cymes. The plant was initially identified as S. lanaensis Merr. because of its abaxially setose leaves and very short inflorescences. However, review of literature, comparison with protologues and herbarium specimens in JSTOR proved that the specimen represents an undescribed taxon. Thus, we here formally describe and name this new species as Saurauia abbreviata K.R.Mazo. This discovery is the latest addition to the genus after an 87-year gap in knowledge in studying this taxon of Actinidiaceae in the Philippines. It further raises the number of recognized endemic species of Saurauia in the country to 57. Moreover, Saurauia longipedicellata Merr. is also rediscovered almost a century since it was first described. Following the International Code of Nomenclature for algae, fungi, and plants (Turland et al. 2017) (ICN), we here assign a lectotype among its syntypes to stabilize this name. Photos, taxonomical and ecological notes, including and an amended description, are also provided.

\section{MATERIALS AND METHODS}

Initial description of the plants were done in situ. Further description was made using dried herbarium and spirit specimens. Botanical illustrations of the new species and S. longipedicellata were created from photographs of living plants and specimens preserved in spirit. Morphological comparisons to similar species were made using herbarium specimens. Images of type specimens deposited in JSTOR Global Plants (continuously updated) were likewise analyzed. All vegetative characters were observed and recorded in the field and reproductive characters were based on fresh and preserved material. The amended description of S. longipedicellata was based on the original description and supplemented by the specimen vouchered by the first author. All specimens were vouchered using the Wildlife Gratuitous Permit: G.P. No. R-IX-03-2021 (New) granted by the Department of Environment and Natural Resources (DENR) Region IX. Herbaria abbreviations follow Thiers et al. 2020 (continuously updated).

\section{TAXONOMIC TREATMENT}

\section{Saurauia abbreviata K.R.Mazo, sp. nov. (Figures 2, 3)}

Type: Philippines: Mindanao: Zamboanga Del Norte Province, Municipality of Leon B. Postigo, Barangay Tinuyop, secondary lowland forest, $8^{\circ} 4^{\prime} 27^{\prime \prime} \mathrm{N}$, $122^{\circ} 56^{\prime} 25^{\prime \prime}$ E, ca. 331 masl elevation, 06 February 2021, KRM 0014 (holotype: $\mathrm{PNH}$; isotype: $\mathrm{CMUH}$ ).

\section{Diagnosis}

Saurauia abbreviata closely resembles Saurauia lanaensis Merr. by having densely setose branchlets, abaxially setose leaves, small, axillary, cymose inflorescence; setaceous sepals; short sepals and petals. However, the new species can be differentiated by having longer petioles $(1.5-4.0 \mathrm{~cm}$ vs. $1.0-1.5 \mathrm{~cm}$ ), uniformly setose adaxial leaf surface ( $v s$. glabrous), longer and wider leaves $(20-42 \mathrm{~cm}$ long $\times 9.5-17 \mathrm{~cm}$ wide $v s .11-20 \mathrm{~cm}$ long $\times 3.0-6.0 \mathrm{~cm}$ wide), more lateral veins $(14-25$ pairs vs. 10-12 pairs). In terms of floral characters, S. lanaensis has slightly larger petals and sepals vs. S. abbreviata. Notably, the older inflorescences in S. abbreviata forms a slightly thick woody rachis from which new flowers emerge after the senescence of the older ones-a characteristic not known to occur in S. lanaensis.

\section{Description}

Habit: small terrestrial tree, ca. $3.5 \mathrm{~m}$ high, 10-15 $\mathrm{cm}$ (diameter at breast height), bark color grayish to brown, lenticels sparse. Branchlets terete, brown-green, densely setose (hairs $0.5-3.7 \mathrm{~mm}$ ) when old; larger setae lanceolate, antrorse, the smaller ones ciliate or reduced setae. Leaves alternate, simple, blade oblanceolate to obovate, chartaceous, $20-42 \mathrm{~cm}$ long $\times 9.5-17 \mathrm{~cm}$ wide, apex cuspidate, base sub-oblique to cuneate, margin entire, setae (1.0-2.0 $\mathrm{mm}$ ) antrorse, curved, uniformly distributed on the margin; adaxial surface green, uniformly setose (hairs $1.5-2.7 \mathrm{~mm}$ long), setae thin, erect, pale green or brown, distributed on the midrib, veins, and reticulations; typically denser at the midrib; abaxial surface pale green, pubescent, ascending on the mid- 

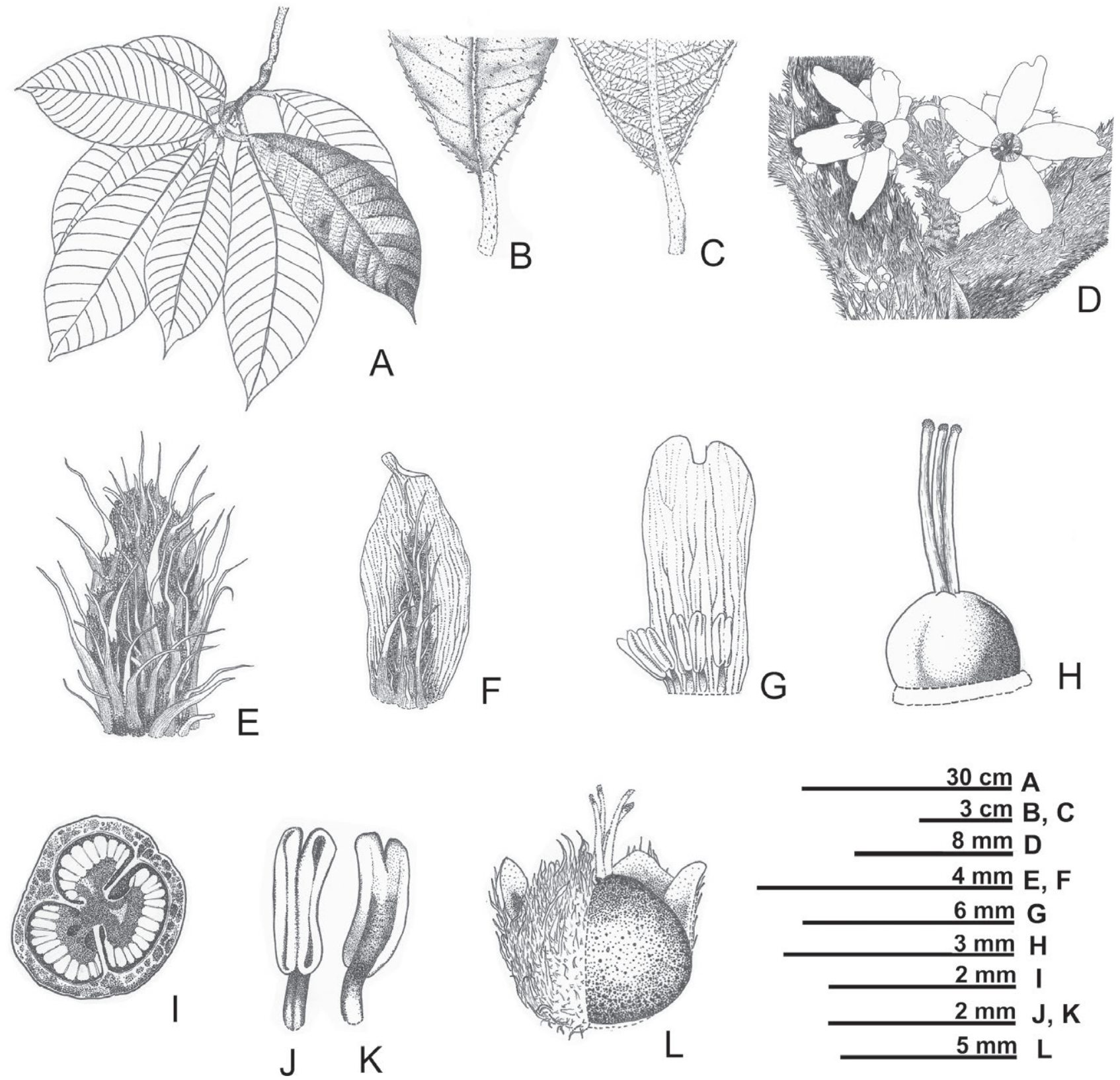

Figure 2. Saurauia abbreviata K.R.Mazo sp. nov. A. Habit; B. Leaf (adaxial view); C. Leaf (abaxial view); D. Inflorescence; E. Outer sepal; F. Inner sepal; G. Petal and stamens; H. Pistil; I. Cross section of the ovary; J. Stamen (anterior view); K. Stamen (posterior view); L. Fruit (remnant sepal removed). Illustrated by Jayson Mansibang.

rib, including the veins, and reticulations; midrib with sparse lanceolate setae with aristate tips, appressed, antrorse; lateral veins $14-25$ pairs, reticulate veined, slightly arching and anastomosing towards leaf margin, secondary veins less prominent, slightly canaliculate adaxially, raised abaxially; submarginal veins $1.0-3.0$ $\mathrm{mm}$ apart from the margin; petiole terete, green, 1.5$4.0 \mathrm{~cm}$ long $\times 0.18-0.36 \mathrm{~cm}$ wide, densely setose (hairs
1-2.5 mm long), larger setae lanceolate with aristate tips, appressed, antrorse, smaller ones ciliate or reduced setae. Inflorescences short, axillary, solitary or short fasciclecymose, $1.5-2.0 \mathrm{~cm}$ long, older inflorescence forms a short woody rachis, $5.0 \mathrm{~mm}$ long $\times 3.0 \mathrm{~mm}$ wide, $3-5$ flowered, lustrous white, few in anthesis at a time. Bracts 2, linear lanceolate, $2.5-3.0 \mathrm{~mm}$ long, both bracts and bracteoles densely setose (hairs $1.0-2.0 \mathrm{~mm}$ long), larger 


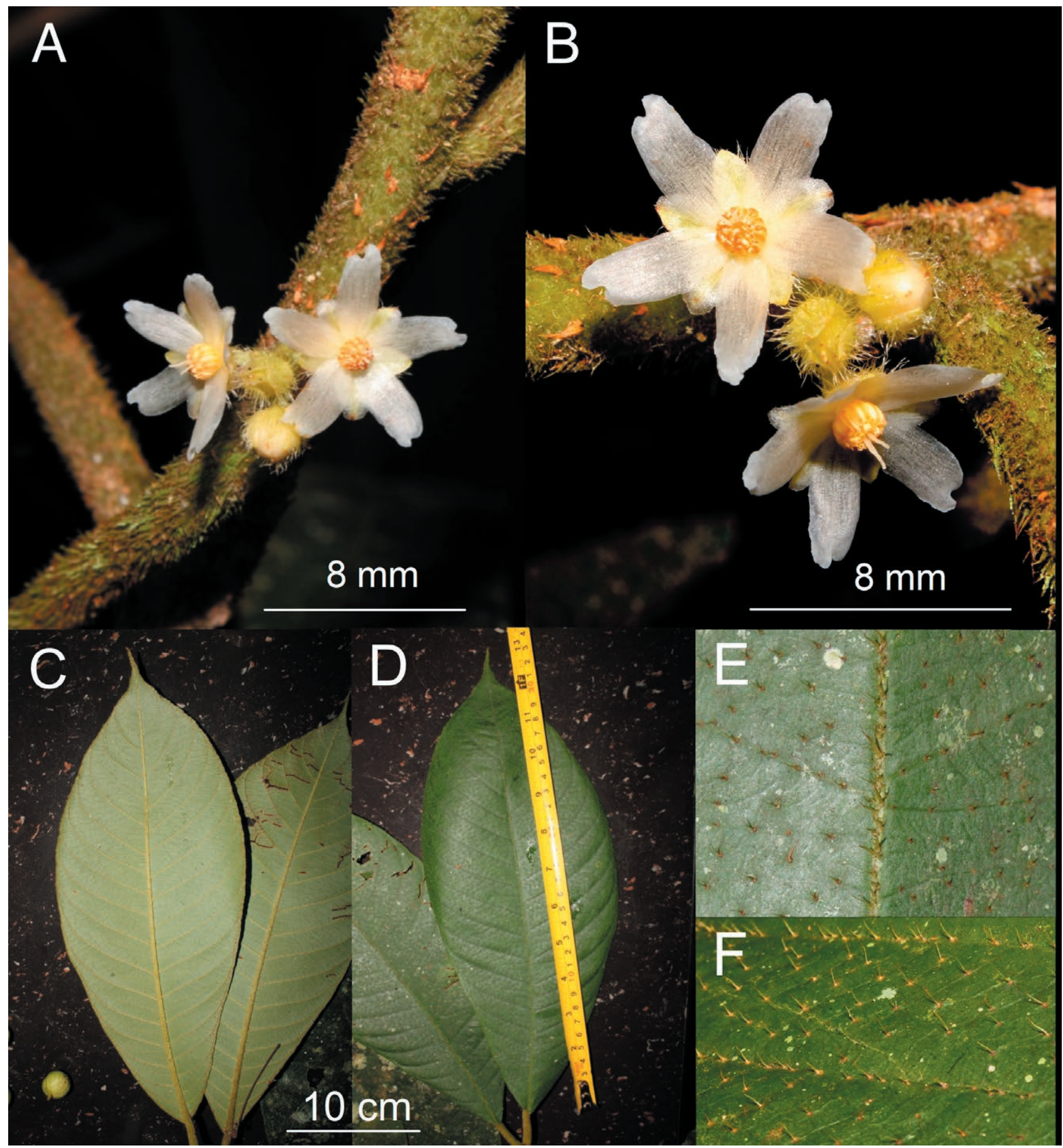

Figure 3. Saurauia abbreviata, sp. nov. A \& B. Inflorescence; C. Leaf (abaxial view); D. Leaf (adaxial view); E. Abaxial leaf setae (close up); F. Adaxial leaf setae (close up). Photos by Kean Roe Mazo.

setae appressed, slenderly lanceolate with apiculate tips; peduncle $3.0-7.0 \mathrm{~mm}$ long, pale green, densely setose (hairs $0.5-1.0 \mathrm{~mm}$ long); bracteoles 2, linear lanceolate, $1.0-2.0 \mathrm{~mm}$ long, smaller than bracts. Pedicels 3.0-4.0 $\mathrm{mm}$ long, pale green, densely setose (hairs $0.5-1.0 \mathrm{~mm}$ long). Sepals 5-merous, almost equal in size, pale green, entire, ovate-lanceolate, $3.5-4.0 \mathrm{~mm}$ long (excluding setae) $\times 2.0-2.5 \mathrm{~mm}$ wide, apex bluntly acute-obtuse, outer and inner sepals adaxially glabrous; outer sepals abaxially densely setose (hairs $0.5-3.0 \mathrm{~mm}$ ) throughout 
the surface, larger setae slenderly lanceolate with apiculate tips; inner sepals abaxially densely setose but only at the median portion (glabrous at the margins). Petals 5-merous, lustrous white, narrowly oblong, $6.0 \mathrm{~mm} \times$ 2.0-3.0 mm, apex notched, sinus $0.5-0.7 \mathrm{~mm}$ long, glabrous. Stamens 20-30, yellow, in two series, adnate to the corolla, filaments $0.5-0.6 \mathrm{~mm}$ long, glabrous; anthers 1.2-1.5 mm long $\times$ ca. $0.5 \mathrm{~mm}$ wide, oblong, dorsifixed, longitudinally dehiscent, apex divided into 2 lobes, $0.2-$ $0.3 \mathrm{~mm}$ long, inner stamens slightly smaller than outer one. Ovary ca. $2.0 \mathrm{~mm}$ long $\times 2.0-3.2 \mathrm{~mm}$ wide, globose, glabrous, pale green-white; locules $3(-4)$, placentation axile, ovules numerous. Styles $2.5-2.7 \mathrm{~mm}$ long, 3(-4), filiform, terete, pale green-white, united at the base for $0.1-0.2 \mathrm{~mm}$, upper arms free, stigma capitate, minutely corniculate. Fruits a berry, globose, glabrous, dark olive-green, $4.0-5.0 \mathrm{~mm}$ long $\times 5.0-7.0 \mathrm{~mm}$ wide (styles excluded), solitary or a few per infructescence, styles caducous or nearly so, sepals persistent at base, apically splitting. Seeds black, numerous, not embedded on mucilaginous matrix.

\section{Etymology}

The specific epithet abbreviata is derived from the Latin word "brevis" (short) in reference to the very short or shortened inflorescences and flower dimensions of the new species-character combinations which are very rarely observed among Philippine Saurauia species.

\section{Distribution and Habitat}

Saurauia abbreviata is only known from the type locality, inhabiting secondary tropical lowland evergreen rainforest at ca. 331 masl composed of trees such as Shorea contorta S.Vidal, S. squamata (Turcz.) Benth. \& Hook. with epiphytes such as Freycinetia Gaudich. species. The understory comprises Zingiber Boehm. sp., Syzygium angulatum (C.B.Rob.) Merr., and weak herbs including Alocasia sanderiana W. Bull, Begonia oblongata Merr., and Elatostema zamboangense Merr. All individuals were observed growing near streams, in partially to fully shaded areas.

\section{Phenology}

Flowering from July to August; fruiting from January to February.

\section{Proposed Conservation Status}

There were only around 20-30 individuals seen in the type locality, along the stream. There is an adjacent forested area, but it has not yet been fully explored. Considering the sampling limitations and the lack of con- crete data to establish a putative assessment, we propose it to be listed under the Data Deficient (DD) category (IUCN Standards and Petitions Committee 2019).

\section{Notes}

S. abbreviata bears some similar characters to $S$. bakeri Merr. and S. clementis Merr. in terms of its dense indumentum in its branchlets, abaxial lamina, inflorescence, sepals, and locule-style number (S. clementis also has a uniformly distributed setae on its adaxial surface). However, both S. bakeri and S. clementis are clearly distinct from $S$. abbreviata by bearing smaller leaves, fewer lateral nerves, distinctly long peduncled inflorescence, and larger flowers. Likewise, the new species is somewhat close to S. elmeri Merr. by its much-reduced inflorescence, however the leaf and flower characters of the new species cannot be mistaken.

The knowledge gap, not only about the Zamboanga region but also the Philippine flora, is not yet fully resolved and many genera still need urgent taxonomic attention. Majority are still only known from one or two collections (including S. lanaensis). Amending the description and finding the type population is integral to this step. Unfortunately, threat of habitat destruction, armed conflict, and climate change hinders conservation and taxonomic efforts. The habitat of the new species is likewise within the ancestral land of the indigenous people in Zamboanga. The Subanen people call S. abbreviata 'himag-puti' and is traditionally used as an ointment for wounds along with other Saurauia species found in the type locality.

Rediscovery and lectotypification of Saurauia longipedicellata Merr.

Saurauia longipedicellata Merr. is rediscovered after almost a century from the forest of the Municipality of Leon B. Postigo, growing sympatrically with S. abbreviata sp. nov. As part of the study towards a revision and improving the species definition of Philippine Saurauia, an amended description of the species is provided here. Moreover, no holotype had been assigned in the protologue of S. longipedicellata. Thus, we assume that all extant specimens bearing the collection BS 36897 Ramos \& Edaño are syntypes. The specimen deposited at $\mathrm{K}$ in our opinion matches the current circumscription of this species and best represents this taxon. We therefore assign it as the lectotype following the ICN (Turland et al. 2017). The specimen from $\mathrm{K}$ shows consistent diagnostic characters with respect to the rediscovered population as vouchered by KRFM (KRM 0016) and the original description (i.e. glabrous branchlets and leaves, 
axillary and cauline positioned inflorescences with very long pedicels). All the remaining extant specimens with the same collection number of this species are therefore treated as isolectotypes.

Saurauia longipedicellata Merr., Philipp. J. Sci. 20, 1922: 407 (Figures 4, 5).

Type: Malangas, Zamboanga Sibugay, Mindanao, Philippines, in forest along streams at low altitudes, November 1919. BS 36897 Ramos \& Edaño. Lectotype here designated: K000761737! (Fig. 6); isolectotype: US1264759!.

\section{Description}

Habit small tree, ca. $7 \mathrm{~m}$ high, $8.8 \mathrm{~cm}$ (diameter at breast height), bark color rufous brown-beige. Branchlets terete, about $5.0 \mathrm{~mm}$ in diameter, green when young, brown when old, entirely glabrous with sparse minute warts and scales on branchlets. Leaves alternate, simple; blade oblanceolate, chartaceous-subcoriaceous, $11-20 \mathrm{~cm}$ long $\times 4.0-5.5 \mathrm{~cm}$ wide, apex rather abruptly and shortly acuminate, base cuneate, sub-oblique, margin entire from the base to the lower half or upper two-thirds, the upper half or a third to the apex denticulate; brown when dry, slightly shiny, adaxial surface green, entirely glabrous or with sparse minute warts at the midrib; abaxial surface pale, glabrous with sparse minute warts and scales on the midrib, lateral veins, and reticulations; lateral veins pinnate, (14-16 pairs), abruptly curved and ascending, raised abaxially; secondary veins less prominent, slightly canaliculate adaxially. Inflorescences axillary or cauliflorous, fascicled, $1.0-1.8 \mathrm{~cm}$ wide, on the trunk and larger branches, few flowers in anthesis at a time; each pedicel is attached to a lignified tubercle, individual rachis $2.6 \mathrm{~mm}$ long $\times 2.0 \mathrm{~mm}$ wide with pairs of linear-triangular scales subtending the pedicel attachment (scales $0.6-0.8 \mathrm{~mm}$ long $\times 0.5-1.0 \mathrm{~mm}$ wide). Bracts 2, lanceolate, 1.0-3.0 $\mathrm{mm}$ long $\times 0.6 \mathrm{~mm}$ wide, located at or near the middle of the pedicel, glabrous, appressed to the pedicel. Pedicels glabrous, terete, red-pink, slender, (3-)4-5 cm long. Sepals 5-merous, pinkish white; outer 2 sepals ellipticovate, $2.0-3.5 \mathrm{~mm}$ long $\times 1.78-2.0 \mathrm{~mm}$ wide, glabrous on both surface; inner sepals petaloid, quite rigid only at the median portion, orbicular-elliptic, $4.0-5.0 \mathrm{~mm}$ long $\times 3.7-5.0 \mathrm{~mm}$ wide, broadly rounded, glabrous on both surfaces. Petals 5-merous, pinkish, broadly oblong, 7-8 $\mathrm{mm}$ long $\times 4-6 \mathrm{~mm}$ wide, entire, apex notched, sinus $1.4-2.0 \mathrm{~mm}$ long, glabrous on both surfaces. Stamens $15-20$, in one series, adnate to the corolla; filaments $2.0-2.3 \mathrm{~mm}$ long, glabrous; anthers $1.9-2.5 \mathrm{~mm}$ long $\times 0.7-1.2 \mathrm{~mm}$ wide, oblong, dorsifixed, longitudinally dehiscent, apex divided into 2 lobes, $0.2-0.4 \mathrm{~mm}$ long. Ovary globose, glabrous, white, $1.6 \mathrm{~mm}$ long $\times$ $2.2 \mathrm{~mm}$ wide; locules $3(-4)$, placentation axile, ovules many. Styles (2.7-4.0 mm long) 3(-4), filiform, terete, white, united only at the point of attachment, upper arms free, stigma capitate, corniculate. Fruit berry, few per infructescence, globose-ovoid, glabrous, pink-white, ca. $9.0 \mathrm{~mm}$ long $\times 6.0-9.0 \mathrm{~mm}$ wide (styles excluded); styles quite persistent or nearly so, sepals persistent at base, apically splitting. Seeds black, embedded in mucilaginous matrix, numerous.

\section{Notes}

S. longipedicellata is unique and strongly characterized by being entirely glabrous (Merrill 1922). The specific epithet pertains to its long pedicels-the strongest diagnostic characteristic of the taxon. However, upon closer examination, it appears that there are (very) sparse minute warts and/or scales present in localized areas of the plant (at least for the vouchered specimens). But these sparse minute warts or scales needs a magnifying tool to confirm presence and cannot be easily discerned especially in fresh specimens.

Notably, these sparse minute warts and scales present in localized areas of the plant may have been a derived character from the reduction of the setae. The sparse warts are more visible abaxially as compared adaxially on leaves. The pedicels of cauliflorous fascicle are attached to lignified tubercles. The outer sepals are thicker and more rigid compared to the inner sepals which are somewhat petaloid. The style and locule number is 3 (very rarely 4). Nevertheless, all other characters mentioned in the protologue especially that of the long pedicels of both the inflorescence and infructescence of S. longipedicellata is similar for the Zamboanga population.

S. longipedicellata was noted by Merrill (1922) to be closest to S. trunciflora Merr. However, S. longipedicellata can be readily differentiated by the absence of welldeveloped setae on the ultimate branchlets, fewer lateral veins (14-16 pairs vs. 15-20 pairs), inflorescence position (axillary and cauliflorous $v s$. strictly cauliflorous), and longer pedicels [(3-)4-5 cm long vs. 2-3.5 cm long)].

\section{Ecology}

The newly rediscovered population of $S$. longipedicellata Merr. was found in the same locality as S. abbrevia$t a$, sp. nov. Merrill noted that the type population of this taxon was collected in Zamboanga, district of Malangas, lowland forest along streams. Similarly, the rediscovered population of Saurauia collected by the first author were 


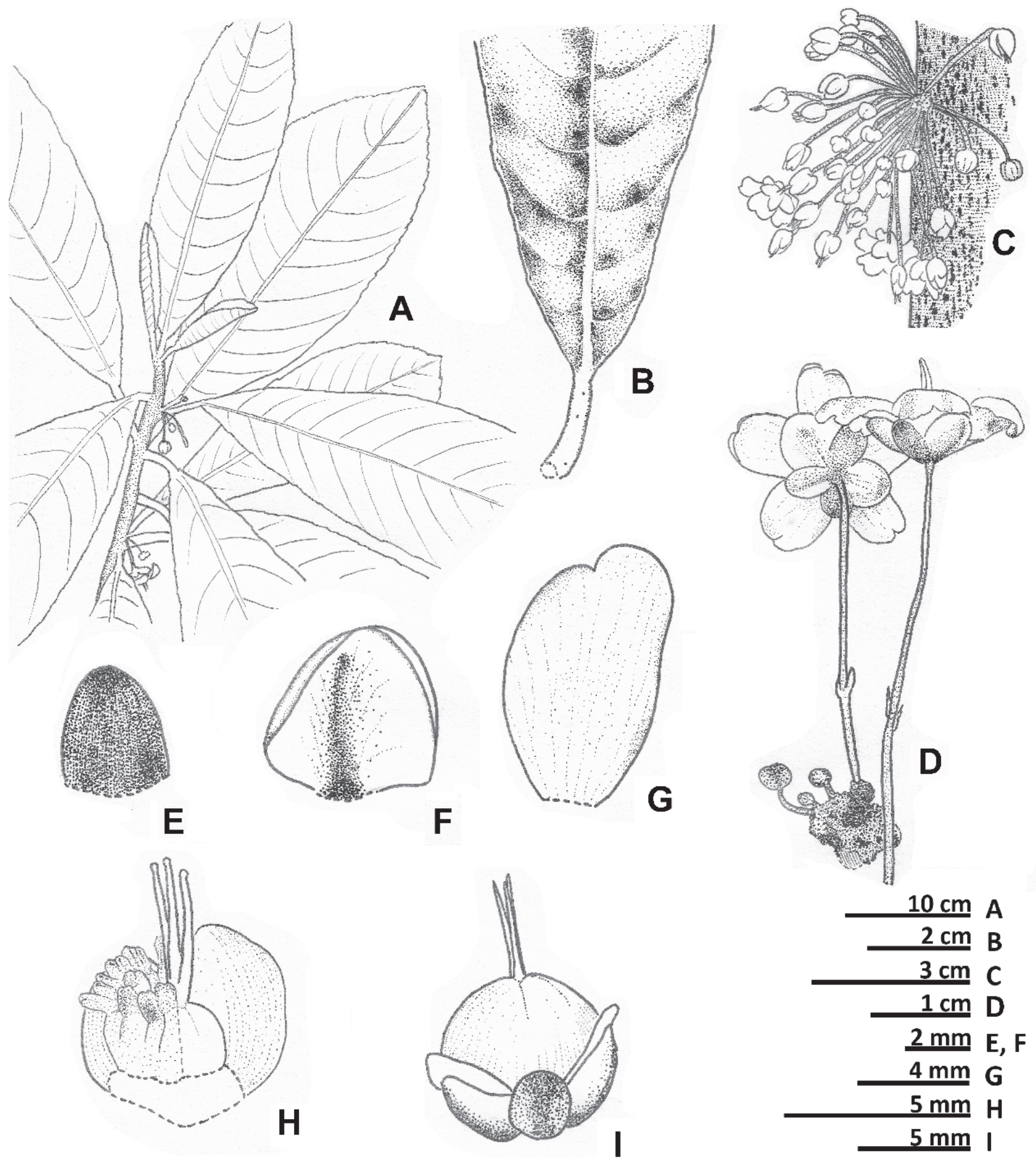

Figure 4. Saurauia longipedicellata Merr. A. Habit; B. Leaf (adaxial view); C. Cauliflorous inflorescence; D. Detail of the flower and tubercle; E. Outer sepal; F. Inner sepal; G. Petal; H. Flower (with portions of corolla and stamens removed). I. Fruit. Illustrated by Jayson Mansibang.

growing in the same ecological conditions, and it has been observed that all other species of Saurauia present in the area prefer the same habitat. At present the habitat preference and ecology of Saurauia species in the Philip- pines is not well understood. Thus, a comprehensive ecological study for Saurauia is recommended to aid future research in this poorly studied genus. 


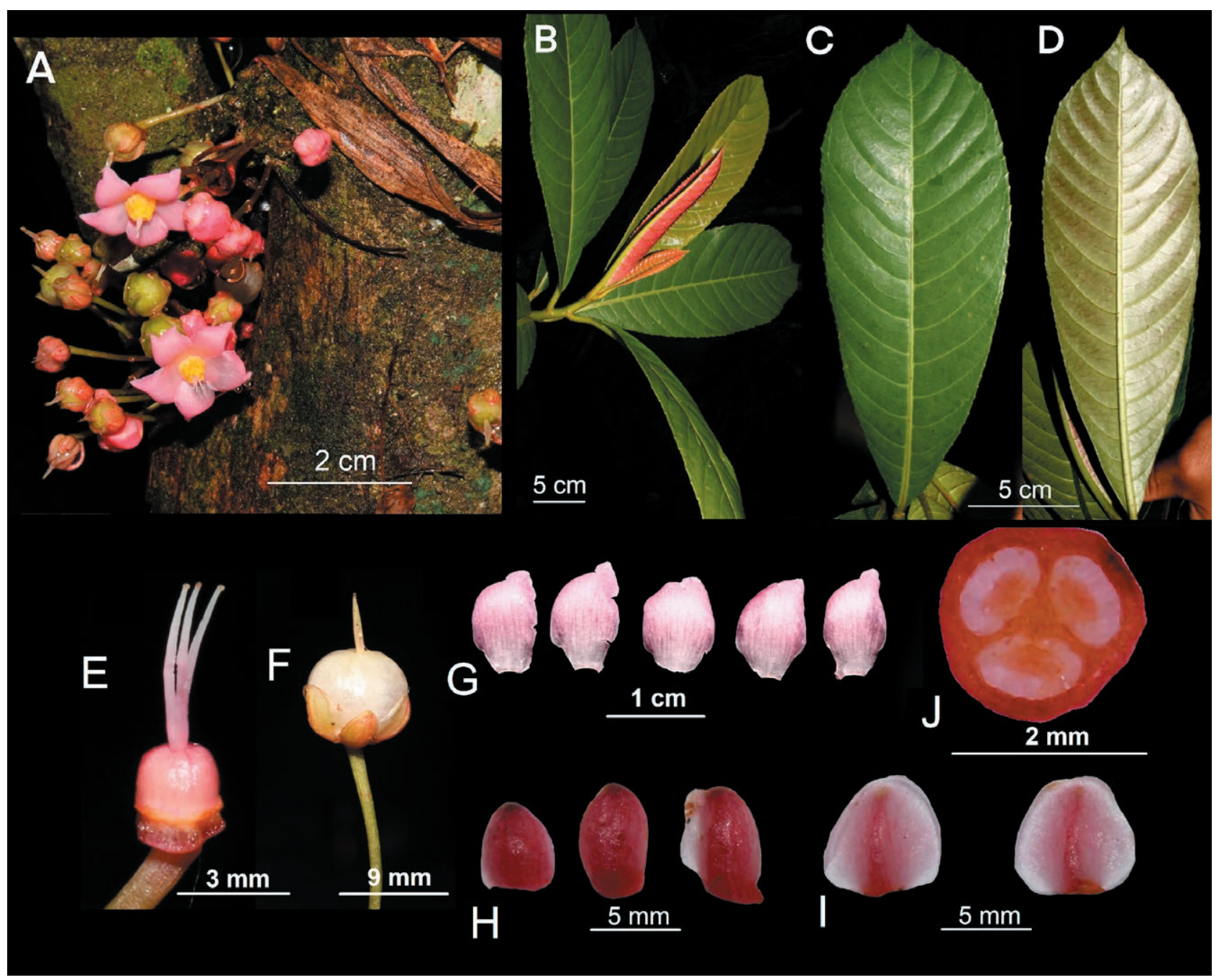

Figure 5. Saurauia longipedicellata Merr. A. Cauline inflorescence; B. Branchlet; C. Leaf (adaxial view); D. Leaf (abaxial view); E. Pistil (perianth removed); F. Fruit; G. Petals; H. External sepals; I. Internal sepals; J. Ovary cross-section. Photos by Kean Roe Mazo.

\section{Proposed Conservation Status}

Though endemic, the difficulty to conduct fieldwork in the areas of extant populations cannot confidently designate a putative conservation status of this species. We thus temporarily assign it as Data Deficient (DD) (IUCN Standards and Petitions Committee, 2019).

\section{ACKNOWLEDGEMENTS}

We would like to express our thanks to the DENR Region IX and the indigenous communities within the Municipality of Leon B. Postigo for their support and issuance of a gratuitous permit. We appreciate the help and assistance of the following: Ms. Abigail Garrino of
PUH-University of the Philippines Diliman; Mr. Rene Alfred Anton Bustamante of the Philippine Taxonomic Initiative, Inc (PTI) for mentoring the second and last authors; Dr. Alan Paton and Dr. Sarah Phillips of the Royal Botanic Gardens Kew for their generosity and kind assistance in the digitization of S. longipedicellata lectotype; and to Prof. Marjorie delos Angeles of the University of the Philippines Los Baños for her initial comments in the paper. Kean Roe F. Mazo would like to thank the Department of Science and TechnologyScience Education Institute (DOST-SEI) and Department of Science and Technology- Science and Technology Regional Alliance of Universities for Inclusive National Development (DOST-STRAND) for his scholarship grant, and to the Philippine Taxonomic Initiative, Inc. for bringing together the expertise of the research- 


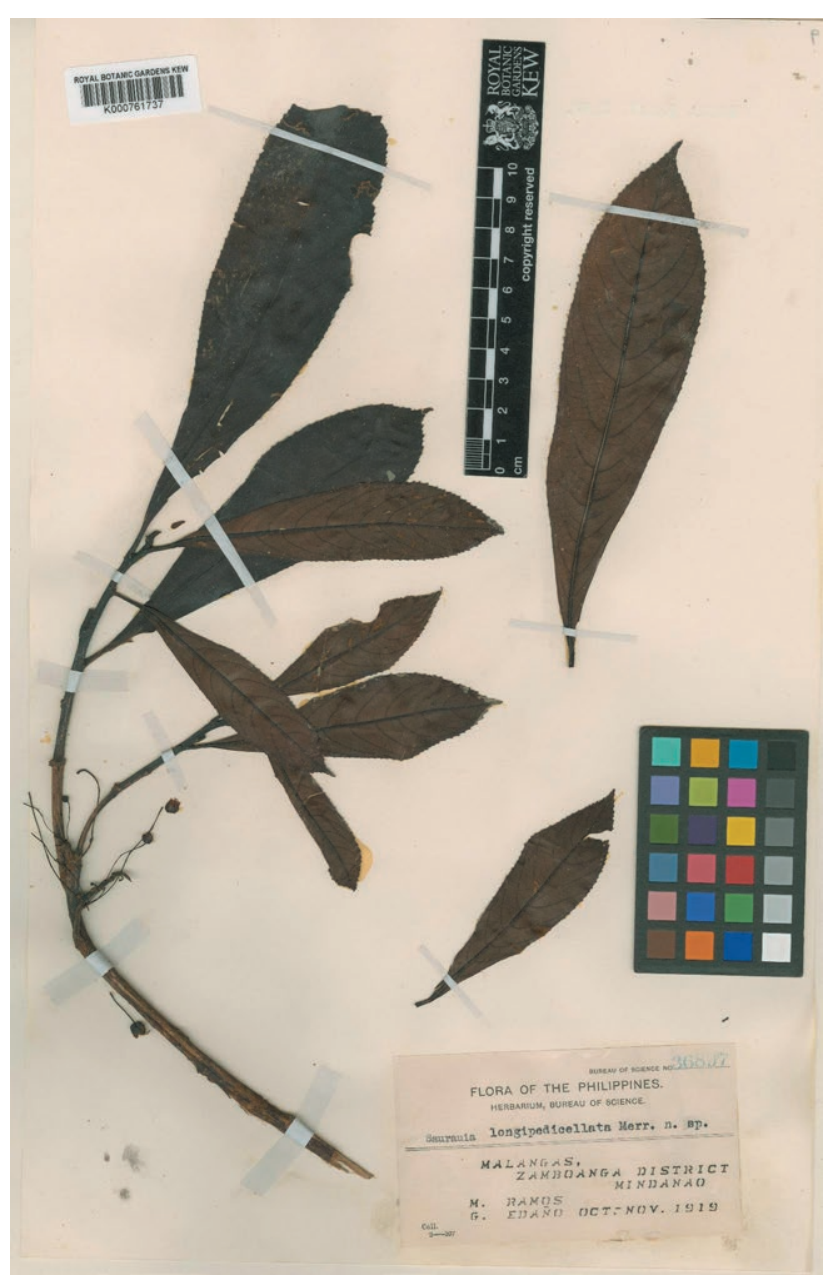

Figure 6. Lectotype of Saurauia longipedicellata Merr. K000761737. Copyright of the Board of Trustees of the Royal Botanic Gardens, Kew (http://specimens.kew.org/herbarium/K000761737).

ers involved in this study. We also thank the comments and suggestions of the reviewers that contributed to the improvement of this manuscript.

\section{REFERENCES}

Barcelona JF, Nickrent DL, LaFrankie JV, Callado JRC, Pelser PB. 2013. Co's Digital Flora of the Philippines: Plant Identification and Conservation through Cybertaxonomy. Philippine Journal of Science. 142: 57-67.

Briggs M. 2015. A New Name in New Guinea Saurauia Willd. Actinidiaceae. Kew Bulletin. 70: 51.

Conn BJ, Damas KG. 2013. A new species of Saurauia (Actinidiaceae) from Papua New Guinea. Telopea. 15: 9-1.
IUCN Standards and Petitions Committee. 2019. Guidelines for Using the IUCN Red List Categories and Criteria. Version 14. Prepared by the Standards and Petitions Committee. Available from: http://www. iucnredlist.org/documents/RedListGuidelines.pdf. (accessed 08 September 2020).

JSTOR Global Plants (continuously updated) https:// plants.jstor.org/ (accessed 24 May 2021).

Merrill ED. 1906. Publications of the Bureau of Science Government Laboratories. Manila. 35: 41-45.

Merrill ED. 1922. New or noteworthy Philippine plants XVII. The Philippine Journal of Science. 20: 407.

Pelser, P.B., J.F. Barcelona \& D.L. Nickrent (eds.). 2011 onwards. Co's Digital Flora of the Philippines. www. philippineplants.org (accessed 08 September 2020).

POWO. 2019."Plants of the World Online. Facilitated by the Royal Botanic Gardens, Kew. Published on the Internet; http://www.plantsoftheworldonline.org/ (20 May 2021).

Thiers, B. 2020. (continuously updated). Index Herbariorum: A global directory of public herbaria and associated staff. New York Botanical Garden's Virtual Herbarium. Available from: http://sweetgum.nybg. org/ih/. (accessed 24 May 2021)

Turland, N. J., Wiersema, J. H., Barrie, F. R., Greuter, W., Hawksworth, D. L., Herendeen, P. S., Knapp, S., Kusber, W.-H., Li, D.-Z., Marhold, K., May, T. W., McNeill, J., Monro, A. M., Prado, J., Price, M. J. \& Smith, G. F. (eds.). 2017. International Code of Nomenclature for algae, fungi, and plants (Shenzhen Code) adopted by the Nineteenth International Botanical Congress Shenzhen, China, July 2017. Regnum Vegetabile. 159. Glashütten: Koeltz Botanical Books. https://doi.org/10.12705/Code.2018

van Welzen, P.C. 2017 (continuously updated). Mrs. M.J. van Steenis-Kruseman's Cyclopaedia of Malesian Collectors. www.nationaalherbarium.nl/fmcollectors (accessed 20 May 2021) 